\title{
VERBA DALAM KALIMAT PASIF BAHASA JEPANG
}

\author{
Lina Rosliana \\ Fakultas Ilmu Budaya Universitas Diponegoro \\ Email : linarosliana251@yahoo.com
}

\begin{abstract}
Verb, is an important element to build a sentence in every language, including Indonesian and Japanese. When we make a complete sentence in Japanese, we use verb as a marker of activity or situation. Like every kind of verb in every language in this world, Japanese verb shows its uniqueness, if we see from the form, the function, or the meaning of it. Verb in Japanese passive voice is marked by-rareru or-reru (V-rareru or V-reru) conjugation that comes in the end of the verb. It stands as a bound morpheme and has a grammatical meaning.
\end{abstract}

Key words: Japanese, verb, passive voice, conjugation

\section{PENDAHULUAN}

Bahasa Jepang, sebagaimana bahasa lainnya, digunakan oleh penuturnya untuk menyampaikan suatu ide, pikiran, hasrat dan keinginan kepada orang lain. Walaupun terkadang digunakan hanya untuk ditujukan pada diri sendiri, seperti pada saat berbicara sendiri baik secara lisan maupun hanya di dalam hati, yang paling penting adalah ide, pikiran, hasrat dan keinginan tersebut dituangkan melalui bahasa.

Ketika kita menyampaikan ide, pikiran, hasrat dan keinginan kita kepada seseorang, baik secara lisan maupun tertulis, orang tersebut bisa menangkap apa yang kita maksud, tiada lain karena ia memahami makna (imi), yang dituangkan melalui bahasa tersebut. Jadi, fungsi bahasa merupakan media untuk menyampaikan (dentatsu) suatu makna kepada seseorang, baik secara lisan maupun tertulis. ( Sutedi, $2003: 2$ )

Untuk dapat menyampaikan ide, pikiran, hasrat dan keinginan tersebut dengan baik, diperlukan pula pemahaman yang baik tentang bahsa yang akan digunakan. Maka disinilah fungsi utama pengkajian secara internal dan eksternal terhadap suatu bahasa. Saat mengkaji bahasa Jepang sebagai bahasa asing secara internal, pengetahuan tentang tata bahasa ( linguistik ) bahasa Jepang menjadi sangat penting. Pengetahuan tentang linguistik ini akan mempermudah dan memperlancar pemahaman dan penguasaan bahasa Jepang. Bagi seorang pengajar bahasa Jepang, tidak mungkin bisa memperbaiki lafal pembelajar dengan baik, jika ia sendiri tidak menguasai bagaimana cara mengucapkan lafal tersebut dengan baik. Hal ini dipelajari dalam bidang fonetik, yang merupakan salah satu cabang linguistik.

Kesalahan berbahasa pada pembelajar, umumnya terjadi karena adanya 'transfer negatif' dari bahasa ibu ke bahasa Jepang. Kesalahan yang muncul bisa berupa penggunaan kosakata, pola kalimat dan sebagainya. ( Sutedi, 2003:1 )

Contoh kasus 'transfer negatif' misalnya, dalam bahasa Indonesia kalimat pasif digunakan cukup produktif, sementara dalam bahasa Jepang tidak demikian, bahkan sebagian besar digunakan untuk menyatakan makna meiwaku ( merasa terganggu ). Tidak sedikit pembelajar bahasa Jepang menggunakan kalimat pasif bahasa Jepang seperti dalam bahasa Indonesia. Hal ini mengakibatkan maksud yang ingin disampaikan tidak termaknai dengan baik. Sehingga untuk menghindari terjadinya 'transfer negatif' ini, mempelajari bagaimana sebenarnya kalimat pasif bahasa Jepang itu, menjadi hal yang mutlak. Banyak keunikan yang menjadi ciri khas 
kalimat pasif bahasa Jepang, yang tidak terdapat dalam bahasa Indonesia.

Bentuk pasif adalah bentuk salah satu bentuk kalimat yang terdapat dalam semua bahasa. Dalam bahasa Jepang, kalimat pasif disebut judoubun atau lebih dikenal dengan ukemi. Bila diartikan secara harfiah ke dalam bahasa Indonesia, ukemi adalah suatu ungkapan yang mengandung arti dimana seseorang mendapat atau menerima perbuatan dari orang lain. Ukemi ditandai dengan kata kerjanya yang berkonjugasi -reru ( V-reru ) dan -rareru ( V-rareru ).

Makino Seiichi dan Tsutsui Michio dalam A dictionary of Basic Japanese Grammar mengatakan bahwa :

"Konsep kalimat pasif dalam bahasa Jepang, yang disebut ukemi ( bentuk yang menerima sesuatu), merupakan hal yang cukup berbeda dengan bahasa Inggris. Kalimat pasif bahasa Jepang mengandung dua elemen, yaitu suatu peristiwa ( sebuah aksi yang dilakukan seseorang, atau sesuatu ) dan seorang manusia atau sesuatu yang mendapat pengaruh dari peristiwa tersebut. “(1986: 33).

\section{KERANGKA TEORETIS}

Onodera (2006), dalam makalahnya yang berjudul Pemikiran Ulang Mengenai Kalimat Pasif Bahasa Jepang (Nihongo no Ukemibun no Saikou) berpendapat bahwa, saat kita melakukan penelitian dengan tema kalimat pasif bahasa Jepang, ada yang harus kita jelaskan terlebih dahulu tentang bentuk predikat dengan konjugasi -rareru (Vrareru) yang dimiliki oleh verba pasif. Hal ini disebabkan oleh adanya kesamaan penggunaan verba berkonjugasi -rareru pada verba pasif dengan bentuk verba yang dimiliki oleh bentuk potensial (kanoukei) dan bentuk hormat (keigo) pada bahasa Jepang.

Asano (2008), dalam sebuah jurnal terbitan Ryukoku University mengutip sebuah pernyataan dari Teramura (1982), hanya dengan menempelkan konjugasi rareru pada sebuah verba, itu akan mengubah hubungan antara unsur pembentuk kalimat, juga akan mengubah kedudukan si pembicaranya. Pernyataan tersebut dapat dijelaskan melalui contoh kalimat di bawah ini:

(1) 私が殴った。 Watashi ga nagutta.

Saya yang memukul.

(2) 私が殴られた。

Watashi ga nagurareta.

Saya yang dipukul.

Kalimat (1) adalah kalimat aktif dengan verba tanpa penanda, yaitu nagutta (memukul). Sedangkan kalimat (2) adalah kalimat pasif dengan verba yang memiliki penanda -rareru, yaitu nagurareta. Verba nagutta, jika ditempeli oleh konjugasi rareru, otomatis akan mengubah makna kalimat, yang semula predikatnya berarti memukul, menjadi dipukul. Kemudian makna partikel ga yang merupakan salah satu unsur pembangun kalimatnya pun berubah, yang semula menunjukkan subjek pelaku perbuatan, berubah menjadi subjek yang dikenai perbuatan. Begitu pula kedudukan si pembicaranya. Kalimat (1) diucapkan oleh pembicara pada kedudukan pelaku, dan kalimat (2) diucapkan pleh pembicara pada kedudukan penerima perbuatan.

Dari dua pernyataan oleh Onodera dan Asano di atas, dapat disimpulkan bahwa bentuk -rareru pada verba pasif merupakan hal yang penting dalam mengkaji kalimat pasif, baik dari segi struktur, maupun makna.

\section{PEMBAHASAN}

Verba bentuk -rareru termasuk ke dalam konjugasi mizenkei (perubahan pada kata kerja, kata sifat, atau kata bantu yang ditandai oleh perubahan bentuk akhir katanya), bersama bentuk menyangkal atau bentuk -nai (V-nai), bentuk maksud atau bentuk -ou/-you (V-ou/ V-you), dan bentuk menyuruh atau bentuk -seru (V-seru). Verba bentuk -nai merupakan dasar dalam pembentukan ukemi dan shieki (kausatif), yaitu dengan cara mengganti akhiran -nai dengan -reru atau -seru untuk verba 
kelompok I, dan -rareru atau -saseru untuk verba kelompok II.

Berikut adalah contoh perubahan verba bentuk -nai ke bentuk -reru dan seru:

Verba Kelompok I

1. ka-wa-nai - kawa-reru - kawa-seru

2. tat-a-nai - tata-reru - tata-seru

3. ur-a-nai - ura-reru - ura-seru

4. kak-a-nai - kaka-reru - kaka-seru

5. oyog-a-nai - oyoga-reru - oyoga-seru

6. yom-a-nai - yoma-reru - yoma-seru

7. sin-a-nai - sina-reru - sina-seru

8. asob-a-nai - asoba-reru - asoba-seru

9. hanas-a-nai - hanasa-reru - hanasa-seru

Verba Kelompok II

10. mi-nai - mi-rareru - mi-saseru

11. ne-nai - ne-rareru - ne-saseru

Verba Kelompok III

12. shi-nai - sa-reru -sa-seru

13. ko-nai - ko-rareru - ko-saseru

Bagan di atas menunjukkan bahwa perubahan kata kerja kalimat pasif memiliki aturan yang sama dengan perubahan kata kerja bentuk menyangkal, yaitu mempertahankan stem atau pangkal katanya, dan merubah hanya bagian akhir dari katanya.

Kalimat pasif bahasa Jepang dapat dibentuk oleh verba transitif maupun intransitif. Berikut adalah contoh kalimat pasif yang berasal dari kalimat aktif transitif dan aktif intransitif:

(3) a. 先生が太郎をほめた。 (kalimat aktif transitif)

Sensei ga Tarou wo hometa.

Guru memuji Tarou.

b. 太郎は先生にほめられた。 (kalimat pasif)

Tarou wa sensei ni homerareta.

Tarou dipuji oleh guru. （4）a. みんなは山田先生を愛した。 (kalimat aktif transitif)

Minna wa yamada sensei wo

aishita.

Semua (murid) mencintai Pak yamada.

b. 山田先生はみんなに愛された。 (kalimat pasif)

Yamada sensei wa minna ni aisareta.

Pak Yamada dicintai (oleh) semua (murid).

(5) a. 雨がふった。 (kalimat aktif intransitif)

Ame ga futta.

Hujan turun.

b. 雨にふられた。(kalimat pasif)

Ame ni furareta.

Kehujanan.

(6) a. 田中さんの弟は事故で死んだ。

(kalimat aktif intransitif)

Tanaka san no otouto wa jiko de shinda.

Adik Tanaka meninggal karena kecelakaan.

b. 田中さんは事故で弟に死なれた。

(kalimat pasif)

Tanaka san wa jiko de otouto ni

shinareta.

Tanaka ditinggal mati adiknya

karena kecelakaan.

Kalimat pasif yang berasal dari kalimat aktif intransitif sebagian besar masuk ke dalam kalimat pasif tak langsung (kansetsu ukemi), dan biasanya memiliki makna adversatif, yaitu si pembicara menderita sesuatu hal yang tidak diinginkan, seperti tampak dalam contoh kalimat berikut:

(7) 友達に来られた。

Tomodachi ni korareta.

Didatangi oleh teman. 
(8) 父に死なれて、困った。

Chichi ni shinarete, komatta.

Ditinggal mati oleh ayah, (saya) merasa susah.

（9）子供に泣かれて、困った。

Kodomo ni nakarete, komatta.

Ditangisi oleh anak, (saya) merasa susah.

Dari beberapa contoh kalimat di atas, bisa diketahui bahwa kalimat pasif tidak langsung sulit untuk diterjemahkan ke dalam kalimat pasif bahasa Indonesia, karena kalimat pasif bahasa Indonesia hanya dibentuk dari kalimat transitif saja. Meskipun demikian, penggunaan kalimat pasif dalam bahasa Jepang bisa dikatakan kurang produktif jika dibandingkan dengan kalimat pasif bahasa Indonesia, karena fungsi utama kalimat pasif bahasa Jepang adalah untuk mengungkapkan perasaan terganggu atau kekecewaan terhadap sesuatu.

\section{SIMPULAN}

Saat mengkaji kalimat pasif, ada banyak hal yang harus diperhatikan sebagai langkah awal. Kita tidak dapat langsung menguraikan makna sebuah kalimat pasif tanpa terlebih dahulu mengerti struktur kalimat pasif itu sendiri. Dan pada saat mengkaji struktur kalimat pasif, tidak lepas dari perubahan bentuk verbanya. Dengan adanya perubahan bentuk verba pada sebuah kalimat, maka terdapat pula perubahan makna dan fungsi dari setiap unsur pembangunnya.

Kalimat pasif bahasa Jepang memiliki penanda konjugasi - rareru pada verbanya (V-rareru). Dari segi makna, konjugasi rareru tersebut selain memberi makna pasif, juga merubah kedudukan si pembicara. Sedangkan dilihat dari penggolongan konjugasinya, V-rareru termasuk ke dalam golongan mizenkei bersama bentuk -nai. Perubahan verba bentuk -nai inilah yang menjadi dasar perubahan verba kalimat pasif.

\section{DAFTAR PUSTAKA}

Isao, Iori. 2001. Atarashii Nihongogaku Nyuumon. Tokyo: Bonjinsha.

Jurnal. Onodera, Michiko. 2006. Nihongo no Ukemibun no Saikou. Takushoku University.

Jurnal. Asano, Mika. 2008. Chokusetsu Ukemi Koubun ni okeru Bougo no Eikyou ni tsuite. Ryukoku University.

Koizumi, Tamotsu. 1993. Nihongo Kyoushi no Tame no Gengogaku Nyuumon. Tokyo: Daishuukan Shoten.

Kridalaksana, Harimurti. 2001. Kamus Linguistik. Jakarta: PT Gramedia Pustaka Utama.

Makino, Seiichi dan Tsutsui, Michio. 1986. A Dictionary of Basic Japanese Grammar. Tokyo. The Japan Times.

Sutedi, Dedi. 2003. Dasar-dasar Linguistik Bahasa Jepang. Bandung: Humaniora. 